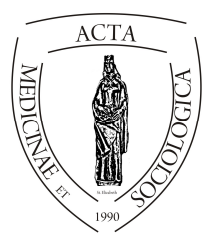

Acta Medicinae et

Sociologica (2019)

UNIVERSITY OF

DEBRECEN

Vol. 10. No. 29. (8-18)

FACULTY OF

HEALTH

doi:

NYÍREGYHÁZA

\title{
A nyíregyházi Huszár- és Keleti lakótelepi vizsgálatok - a kutatás módszertana és a minta néhány alapvető jellemzője
}

\author{
Takács Péter ${ }^{1}$, Huszti Éva $^{2}$ \\ ${ }^{1}$ főiskolai tanár, Debreceni Egyetem Egészségügyi Kar, 4400 Nyíregyháza, Sóstói út 2-4. \\ ${ }^{2}$ főiskolai docens, Debreceni Egyetem Egészségügyi Kar, 4400 Nyíregyháza, Sóstói út 2-4
}

INFO

Takács Péter

takacs.peter@foh.unideb.hu

\section{Keywords}

research methodology,

sampling, socio-

demographic indicators,

disadvantaged settlement areas

\section{ABSTRACT}

\begin{abstract}
Research at the Husar and Eastern settlements in Nyíregyháza - Methodology of the research. This study contains the methodology description of settlement research carried out in Nyíregyháza. A description of geographical location and distinctiveness of the two surveyed places, Husar and Eastern settlements, is followed by an introduction of the main block of the questionnaire used in our research. The surveyed sample is described by its geographical distribution then by the main socio-demographic indicators. 271 households were examined at the two locations by questioners. $69 \%$ of the respondents were women, $31 \%$ of them men, the average age was 43.5 , and rate of those with completed 8 -grade primary school was prominent. The majority of the respondents lived in cohabitation or were unmarried. It is estimated that our data collection covered the $25-35 \%$ of the population in the two settlements. Regarding gender, age, level of education, marital status and economic activity there were no statistical differences between the two settlements.
\end{abstract}

\section{Kulcsszavak:}

kutatásmódszertan, mintavétel, szociodemográfiai mutatók, hátrányos helyzetü településrészek
Absztrakt. A tanulmány a Nyíregyházán végzett lakótelepi kutatások módszertani leírását tartalmazza. A két vizsgálati helyszín, a Huszár lakótelep és a Keleti lakótelep földrajzi elhelyezkedésének, sajátosságainak bemutatását a kutatás során alkalmazott kérdöív főbb blokkjainak ismertetése követi. A vizsgálati mintát a területi megoszlás, majd a főbb szociodemográfiai mutatók mentén írjuk le. A két helyszínen összesen 271 háztartás megkérdezésére került sor kérdezőbiztosok segítségével. A válaszadók $69 \%$-a nő, $31 \%$-a férfi, az átlagéletkor 43,5 év volt és kiemelhető az általános iskolai végzettség nagy 
aránya. A válaszadók legnagyobb része a kérdezés idején élettársi kapcsolatban élö hajadon vagy nőtlen volt. Kutatói becslés szerint az adatfelvétel a nyíregyházi Huszártelep lakosságának 25-35\%-át fedte le. A két településrész között nem jelezhető statisztikai különbség a nem, a kor, az iskolai végzettség, a családi állapot és a gazdasági aktivitás mutatóinak tekintetében.

Ez a tanulmány a TOP-6.9.1-16-NY1-2017-00001 azonosító számú

"Közösen a kiútért" címü projekt támogatásával készült.

\section{Bevezetés}

2019. év elején került sor arra az adatfelvételi munkára, amely Nyíregyházán a Huszár-telep és a Keleti lakótelep lakosainak lakhatási viszonyait, egészségi állapotát és más életkörülményekre vonatkozó fontos kérdéseket volt hivatott megvizsgálni. A két helyszín (1. ábra) Nyíregyházán azok közé tartozik, amelyeket a város legnagyobb szegregátumainak kell tekinteni (Helyi közösségi fejlesztési stratégia 20162020, 2017). Korábbi összesítések szerint „A kb. 120 ezer fős városban a cigány népesség becsült aránya 8 százalék, negyedük a Huszár-telepen él. A lakótelepen élők 85 százaléka roma. ... A KSH 2001-es lehatárolása alapján a Huszártelep minden mutatója (iskolai végzettség, foglalkoztatottság, lakások komfortfokozata stb.) jóval rosszabb nem csak a városi átlagnál, de más szegregált településrészek mutatóinál is. Az alacsony státuszú népesség aránya szinte 100 százalék. (A 2001-es népszámlálási adatok szerint a foglalkoztatási ráta 32 százalékos volt, az aktív korúak kétharmada nem rendelkezett rendszeres munkajövedelemmel. A 14 ével aluliak aránya 50 százalék körüli.)"'. (Összefoglaló, 2012) Sajnos a következő népszámlálás sem mutatott jelentős változást ezen a területen.

Több nézőpontból is szemlélhető a városrész helyzete - speciális viszonyok alakultak ki itt az idők során: „A telepen számos szolgáltatást nyújtanak az ott müködő szervezetek és az önkormányzat (a bölcsődétől az idősek klubjáig). Ez értelmezhető úgy, hogy a város és intézményei, a helyi civilek mindent megtesznek azért, hogy a lakótelepen élők életminőségét - legalább a komplex szolgáltatásokkal - javítsák. Másrészt felmerül a kérdés: mennyiben erősíti a szegregációt az, hogy a Huszártelepen élőknek már szinte semmiért nem kell a „városba” menniük.” (Összefoglaló, 2012)

A nyíregyházán lévő másik szegregált településrész a Keleti-lakótelep, ahol nem zajlottak olyan beruházások és fejlesztések, mint a Huszár-telepen. 


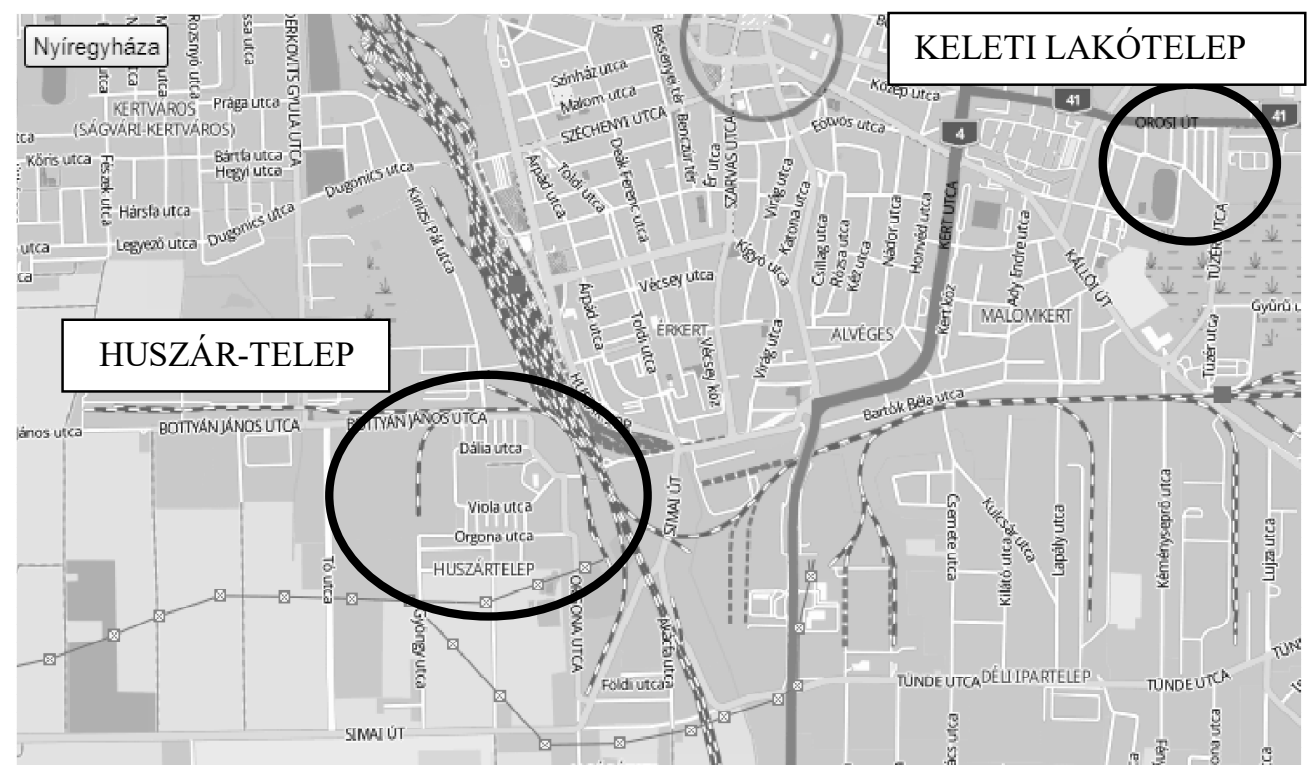

1. ábra - Nyíregyháza térképrészlete, a Huszár-telep (Guszev)

és a Keleti lakótelep megjelölésével (utcakereso.hu)

A két településrészen végzett kutatás egyik fő célja a korábban feltárt helyzetkép további pontosítása, valamint magának a két településrésznek az összehasonlítása. A kialakult és müködő szolgáltatási háttér nyomán vajon objektív mérésekkel is érzékelhető különbségek mutathatók ki, vagy a szubjektív érzéseket és a véletlen kiugrásokat nem meghaladó a településrészek közötti eltérés?

\section{Kérdöív}

A kutatás során alkalmazott kérdőív kialakítása során a kutatócsoport arra törekedett, hogy a vizsgálat eredményei egyrészt a 2008 óta tartó Nyíregyháza Életminősége címü kutatássorozat, másrészt az országos vonatkozó adatokkal összevethetők legyenek. A kérdőív összeállítása során törekedni kellett arra is, hogy a vizsgálat célcsoportjának életminősége, annak javítása szempontjából különösen fontos elemek is bekerüljenek a vizsgálati dimenziók közé.

Ezek figyelembe vételével a következő kérdésblokkok kerültek be a kérdőívbe.

I. Lakáshelyzet, életkörülmények: háztartásban élők száma, összetétele, a ház/lakás nagysága, komfortfokozata, minősége, a lakókörnyezet jellemzői, a lakás fenntartásának költségei, a lakáshoz, lakókörnyezethez való viszony, elköltözési szándék.

II. Jövedelmi helyzet: szubjektív, objektív mutatók.

III. Oktatás, tanulás: a megkérdezett, illetve szülők, gyermekek iskolai végzettsége, az előforduló iskolaelhagyás okai, jövőbeni tervei, továbbtanulás, képzési programokon való részvétel. 
IV. Foglalkoztatás: álláskeresés, elhelyezkedés, munka, munkahely, munkaidő, a foglalkoztatás módja, jelenlegi és korábbi munkaerőpiaci helyzet.

V. Társas kapcsolatok: bizalmas kapcsolatok, barátok száma, gyenge kötések.

VI. Egészségi állapot: szubjektív egészségi állapot, objektív mutatók, szakellátás igénybevétele, szürések, táplálkozás.

VII. Rizikómagatartás: negatív életesemények (RÉS), életminőség (CASP19), dohányzás, alkoholfogyasztás, kábítószerhasználat.

VIII. Támogató rendszerek, szociális problémák: természetes támogatórendszer, segélyek igénybevétele, elégedettség a szociális támogatórendszer egyes elemeivel.

IX. Identitás, hagyományőrzés: milyen nemzetiségünek tartja magát első, illetve másodsorában, nyelvismeret (romani, beás).

X. Közösségi programok, szolgáltatások: meglévő szolgáltatások ismertsége, igénybevétele, tervezett szolgáltatások iránti igény, érdeklődés, aktív részvétel.

\section{Mintanagyság, területi eloszlások}

A kérdezőbiztosok 2019. február 19. és március 19. között összesen 271 címet kerestek fel. A Huszár lakótelepen 201 (74,2\%), a Keleti lakótelepen pedig 70 (25,8\%) háztartás adatai kerültek meghatározásra. Az 1. táblázat lakótelep és utca szerinti bontásban mutatja be a mintát. A legnagyobb arányban a Viola utca és a Dália utca lakói kerültek a mintába (72,33\%). (2. és 3. ábrák)

\begin{tabular}{|l|c|c|r|}
\cline { 2 - 4 } \multicolumn{1}{c|}{} & Keleti lakótelep & Huszár lakótelep & \multicolumn{1}{c|}{$\%$} \\
\hline Csáki István utca & 13 & - & 4,8 \\
\hline Dália utca & - & 73 & 26,9 \\
\hline Gerliczky Mihály utca & 21 & - & 7,8 \\
\hline Huszár tér & - & 5 & 1,9 \\
\hline Tarcsay István utca & 4 & - & 1,5 \\
\hline Tüzér utca & 10 & - & 3,7 \\
\hline Vándlik Márton utca & 22 & - & 8,1 \\
\hline Viola utca & - & 123 & 45,4 \\
\hline
\end{tabular}

1. táblázat - A megkérdezett háztartások utca és lakótelep szerinti megoszlása Forrás: Huszár- és Keleti lakótelepi vizsgálatok, 2019 


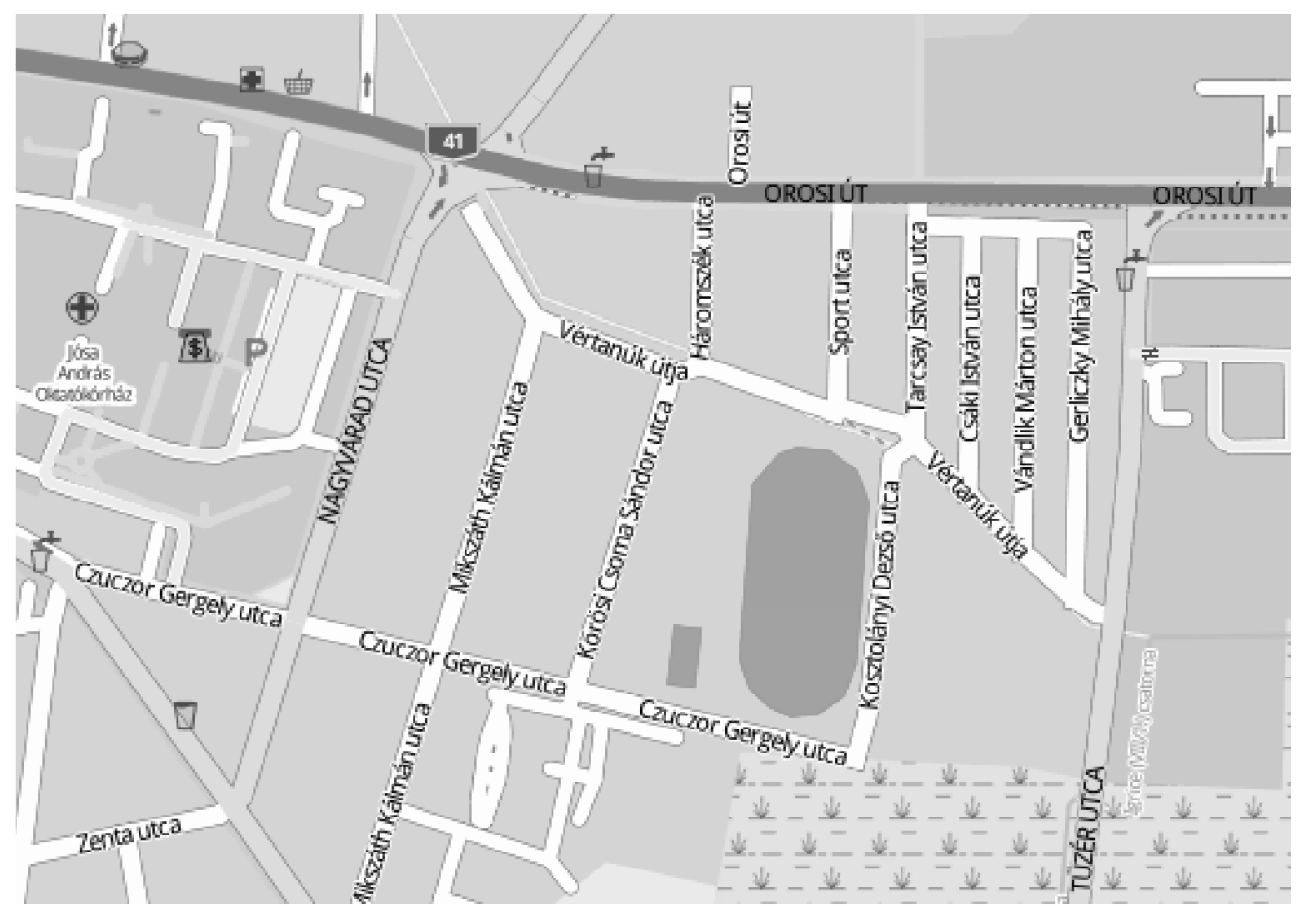

2. ábra - A Keleti lakótelep utcáinak elhelyezkedése (utcakereso.hu)

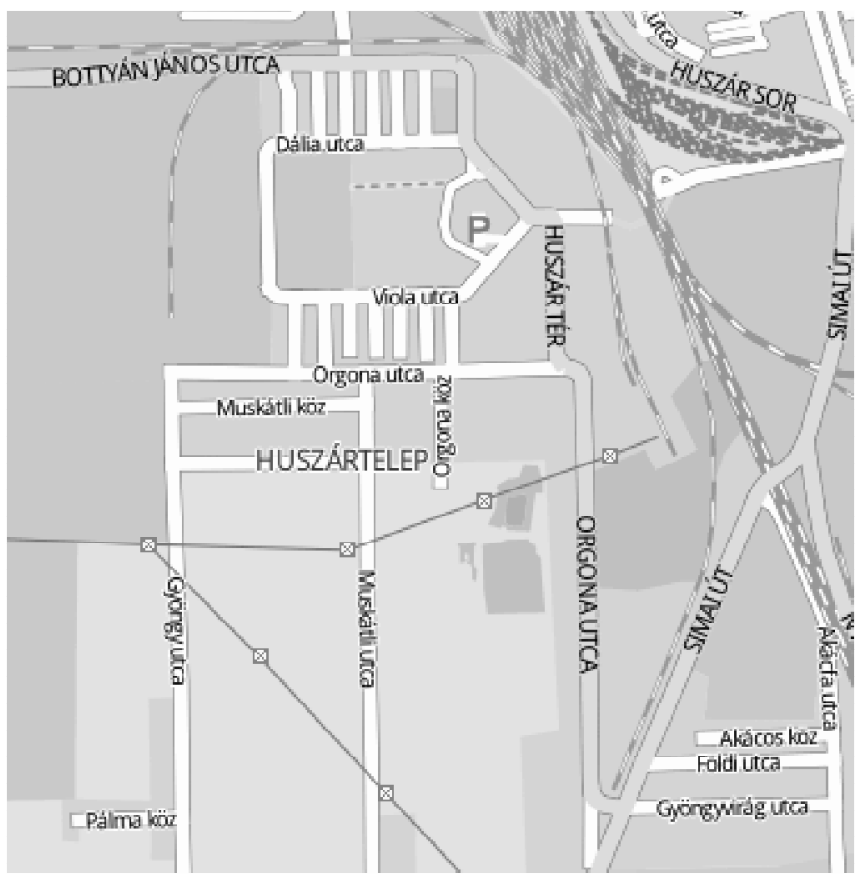

3. ábra - A Huszár-telep utcáinak elhelyezkedése (utcakereso.hu) 


\section{Összes lefedett népesség}

A felmérés során a 271 háztartás közül egyetlen egy nem adta meg a háztartásban élők számát $(0,4 \%)$. A háztartások nagyság szerinti gyakoriságait az 2 . táblázat részletezi. A táblázat felhasználásával becsülhető a felmérés során érintett személyek száma 1089 fö volt (Nyíregyháza lakosságszáma 2018. január 1. 117121 - Helynévkönyv, 2018); a megkérdezettek aránya 6,4\% körüli).

Összesen Önnel együtt hányan élnek egy háztartásban?

\begin{tabular}{|l|c|c|c|c|}
\hline \multirow{4}{*}{$\begin{array}{l}\text { Háztarkák száma } \\
\text { éma }\end{array}$} & fö & gyakoriság & $\%$ & valós \% \\
\cline { 2 - 5 } & 2 & 35 & 12,9 & 13,0 \\
\cline { 2 - 5 } & 3 & 35 & 12,9 & 13,0 \\
\cline { 2 - 5 } & 4 & 47 & 17,3 & 17,4 \\
\cline { 2 - 5 } & 5 & 48 & 18,5 & 18,5 \\
\cline { 2 - 5 } & 6 & 20 & 17,7 & 17,8 \\
\cline { 2 - 5 } & 7 & 13 & 4,4 & 7,4 \\
\cline { 2 - 5 } & 8 & 10 & 3,7 & 4,8 \\
\cline { 2 - 5 } & 9 & 8 & 3,0 & 3,7 \\
\cline { 2 - 5 } & 10 & 4 & 1,5 & 1,5 \\
\cline { 2 - 5 } & Összesen & $\mathbf{2 7 0}$ & 99,6 & 100,0 \\
\hline \multirow{4}{*}{ Hiányzó } & 99 nincs & 1 & 0,4 & \\
\hline Összesen & válasz & $\mathbf{2 7 1}$ & 100,0 & \\
\hline
\end{tabular}

2. táblázat - A háztartásban élők száma

Forrás: Huszár- és Keleti lakótelepi vizsgálatok, 2019

A lakótelepi háztartásnagyságokat az 3. táblázat sorolja fel. Az 1089 fős teljes érintett kör a Huszár lakótelepen 746 fö (70,2\%), a Keleti lakótelepen pedig 325 fö $(29,8 \%)$ volt.

\begin{tabular}{|c|c|c|c|c|c|}
\hline fó & Huszár & $\%$ & Keleti & $\%$ & \% különbség \\
\hline 1 & 26 & 3,40 & 9 & 2,77 & 0,63 \\
\hline 2 & 58 & 7,59 & 12 & 3,69 & 3,90 \\
\hline 3 & 111 & 14,53 & 30 & 9,23 & 5,30 \\
\hline 4 & 160 & 20,94 & 40 & 12,31 & 8,63 \\
\hline 5 & 165 & 21,60 & 75 & 23,08 & $-1,48$ \\
\hline 6 & 102 & 13,35 & 18 & 5,54 & 7,81 \\
\hline 7 & 56 & 7,33 & 35 & 10,77 & $-3,44$ \\
\hline 8 & 40 & 5,24 & 40 & 12,31 & $-7,07$ \\
\hline 9 & 36 & 4,71 & 36 & 11,08 & $-6,36$ \\
\hline \multirow[t]{3}{*}{10} & 10 & 1,31 & 30 & 9,23 & $-7,92$ \\
\hline & 764 fo & 100,00 & 325 fó & 100,00 & 1089 \\
\hline & $70,2 \%$ & & $29,8 \%$ & & $100,00 \%$ \\
\hline
\end{tabular}

3. táblázat - Az érintett lakosságszám lakótelepek szerinti megoszlása Forrás: Huszár- és Keleti lakótelepi vizsgálatok, 2019 
A következő fejezetrészek demográfiai és szociológiai változók közül a legfontosabbakat emeli ki. Ezek a jellemzők a megkérdezettekre vonatkoztathatók - a háztartás szerkezetével, összetételével a következő fejezetrész foglalkozik ebben az írásban.

\section{A válaszadó nem szerinti megoszlása}

A teljes mintában 271 fö válaszolt a nemre vonatkozó kérésre. Közöttük 85 férfi $(31,4 \%)$ és 186 nő $(68,6 \%)$ volt. A Huszár lakótelepen 30,45-69,7\% volt a megkérdezettek között a nemek aránya (61 férfi és 140 nö); a Keleti lakótelepen 34,3\%$65,7 \%$ (24 férfi és 46 nő). A két részminta közötti eltérés nem szignifikáns ( $\chi 2(1, \mathrm{~N}$ $=271)=0,374, p=0,541$; Fisher teszt, $p=0,552$ ).

\section{A válaszadó életkor szerinti megoszlása}

Életkorát 265 válaszadó adta meg. A legfiatalabb 18, a legidősebb válaszoló 77 éves volt (terjedelem 59 év). Átlagéletkornak 43,50 év adódott (95\% CI 41,87-43,13; szórás 13,50). Az életkorok eloszlása a mintában nem alkotott normális eloszlást (Kolmogorov-Szmirnov teszt, $\mathrm{df}=265, \mathrm{p}=0,004$; Shaphiro-Wilk teszt, df $=265, \mathrm{p}$ $=0,000)$. Az eloszlás képe bal oldali asszimetriát, jobbra kissé elnyúló eloszlás képét mutatta.

A Huszár lakótelepen az életkorra vonatkozó kérdésre 197 fó válaszolt, a Keleti lakótelepen 68 fö. Az átlagéletkorok (Huszár-Keleti) 43,63 és 43,10 év voltak (szóródások: 13,47 és 13,61; 95\% CI 41,74-45,53 és 39,79-46,41). A Huszár lakótelep eloszlása nem normális (Kolmogorov-Szmirnov, df $=197, \mathrm{p}=0,000$; Shaphiro-Wilk, df $=197, p=0,000$ ); a Keleti lakótelepé azonban igen (Kolmogorov-Szmirnov, df = $68, \mathrm{p}=0,200$; Shaphiro-Wilk, $\mathrm{df}=68, \mathrm{p}=0,244)$. A két mintarész szignifikánsan nem tért el (független mintás t-próba, $\mathrm{t}(263)=0,280, \mathrm{p}=0,780$ ).

\section{A válaszadó iskolai végzettsége}

Az iskolai végzettséget a kérdőív nyolc lehetséges válaszlehetőséggel mérte. A lakótelepek esetszámait és arányait az 4. táblázat részletezi. A két részminta közötti eltérés nem szignifikáns $(\chi 2(5, \mathrm{~N}=268)=4,552, \mathrm{p}=0,497$; Fisher teszt, $\mathrm{p}=0,622)$. Kiemelhető az általános iskolai végzettség nagy aránya (a teljes mintában hatvan százalék körüli); felsőfokú végzettség egyetlen egy főnél jelenik meg. A középfokú végzettségüek 18-24\%-os arányban vannak jelen.

A 2011-es népszámlálási adatok szerint Nyíregyházán az általános iskola első évfolyamát sem elvégzők aránya (10 éves kor felett vizsgálva a megkérdezetteket) $0,5 \%$; ugyanez az érték a Nyíregyházi járásban 0,6\%; Szabolcs-Szatmár-Bereg megyében 1,0\%. (Malakucziné, 2015) 


\begin{tabular}{|c|c|c|c|}
\hline & Huszár lakótelep & Keleti lakótelep & Összesen \\
\hline \multirow{2}{*}{$\begin{array}{l}\text { 1. kevesebb, mint } 8 \text { általá- } \\
\text { nos }\end{array}$} & 31 & 13 & 44 \\
\hline & $15,6 \%$ & $18,8 \%$ & $16,4 \%$ \\
\hline \multirow{2}{*}{ 2. 8 általános } & 115 & 44 & 159 \\
\hline & $57,8 \%$ & $63,8 \%$ & $59,3 \%$ \\
\hline \multirow{2}{*}{$\begin{array}{l}\text { 3. szakmunkásképzö, } \\
\text { szakképzés érettségi nélkül }\end{array}$} & 43 & 12 & 55 \\
\hline & $21,6 \%$ & $17,4 \%$ & $20,5 \%$ \\
\hline \multirow{2}{*}{$\begin{array}{l}\text { 4. szakközépiskolai érett- } \\
\text { ségi/szakképzést követő } \\
\text { érettségi }\end{array}$} & 5 & 0 & 5 \\
\hline & $2,5 \%$ & $0,0 \%$ & $1,9 \%$ \\
\hline \multirow{2}{*}{$\begin{array}{l}\text { 7. felsőfokú szakképzés, } \\
\text { felsőfokú technikusm }\end{array}$} & 1 & 0 & 1 \\
\hline & $0,5 \%$ & $0,0 \%$ & $0,4 \%$ \\
\hline \multirow{2}{*}{ 8. föiskola } & 4 & 0 & 4 \\
\hline & $2,0 \%$ & $0,0 \%$ & $1,5 \%$ \\
\hline \multirow{2}{*}{ Összesen } & 199 & 69 & 268 \\
\hline & $100,0 \%$ & $100,0 \%$ & $100,0 \%$ \\
\hline
\end{tabular}

4. táblázat - Az iskolai végzettség lakótelepek szerinti megoszlása Forrás: Huszár- és Keleti lakótelepi vizsgálatok, 2019

\section{A válaszadó családi állapota}

\begin{tabular}{|c|c|c|c|}
\hline & Huszár lakótelep & Keleti lakótelep & Összesen \\
\hline \multirow{2}{*}{ 1. nőtlen/hajadon, nincs élettársa } & 45 & 16 & 61 \\
\cline { 2 - 4 } & $23,7 \%$ & $24,2 \%$ & $23,8 \%$ \\
\hline \multirow{2}{*}{ 2. nötlen/hajadon, élettárssal él } & 52 & 26 & 78 \\
\cline { 2 - 4 } & $\mathbf{2 7 , 4 \%}$ & $\mathbf{3 9 , 4 \%}$ & $30,5 \%$ \\
\hline \multirow{2}{*}{ 3. házas, házastárssal él } & 42 & 14 & 56 \\
\cline { 2 - 4 } & $22,1 \%$ & $21,2 \%$ & $21,9 \%$ \\
\hline \multirow{2}{*}{ 4. házas, élettárssal él } & 6 & 1 & 7 \\
\cline { 2 - 4 } & $3,2 \%$ & $1,5 \%$ & $2,7 \%$ \\
\hline \multirow{2}{*}{ 5. házas, de külön élnek, nincs } & 1 & 0 & 1 \\
\cline { 2 - 4 } élettársa & $0,5 \%$ & $0,0 \%$ & $0,4 \%$ \\
\hline \multirow{2}{*}{ 6. elvált, nincs élettársa } & 13 & 3 & 16 \\
\cline { 2 - 4 } & $6,8 \%$ & $4,5 \%$ & $6,3 \%$ \\
\hline \multirow{2}{*}{ 7. elvált, élettárssal él } & 8 & 1 & 9 \\
\cline { 2 - 4 } & $4,2 \%$ & $1,5 \%$ & $3,5 \%$ \\
\hline \multirow{2}{*}{ 8. özvegy, nincs élettársa } & 21 & 5 & 26 \\
\cline { 2 - 4 } & $11,1 \%$ & $7,6 \%$ & $10,2 \%$ \\
\hline \multirow{2}{*}{ 9. özvegy, élettárssal él } & 2 & 0 & 2 \\
\cline { 2 - 4 } & $1,1 \%$ & $0,0 \%$ & 256 \\
\hline \multirow{2}{*}{ Összesen } & 190 & 66 & $100,0 \%$ \\
\cline { 2 - 4 } & $100,0 \%$ & $100,0 \%$ & \\
\hline
\end{tabular}

5. táblázat - A családi állapot lakótelepek szerinti megoszlása

Forrás: Huszár- és Keleti lakótelepi vizsgálatok, 2019 
A megkérdezettek családi állapot szerint legjellemzőbben a nőtlen/hajadon/élettárssal él kategóriát jelölte meg. A minta négyötöde $(78,9 \%)$ vagy egyedülállónak vallotta magát (1. kategória) vagy házastársi/élettársi kapcsolatot jelölt meg (2.-4. kategória) 5. táblázat. A két részminta közötti eltérés nem szignifikáns $(\chi 2(8, \mathrm{~N}=256)=5,883, \mathrm{p}$ $=0,679$; Fisher teszt, $\mathrm{p}=0,794)$.

A 15 éves és idősebb nyíregyházi népesség családi állapot szerinti megoszlása 2011-ben a táblázatbeli értékektől eltérő képet mutat: magasabb például a házasok és élettársi kapcsolatban élök aránya (férfiak 59,8\%; nők 50,4\%; középérték 55,1\%). Alacsonyabb a nőtlenek/hajadonok aránya (férfiak 35,8\%; nők 27,5\%; középérték 31,65\%). (Malakucziné, 2015)

\section{A válaszadó gazdasági aktivitása}

A foglalkoztatási arányokat az 6. táblázatba összegyüjtött adatok és arányok jelzik a mintában. Az aktuális és az előző tizenkét hónapban történt foglalkoztatási arányok különbsége (húsz százalék körüli eltérés) jelzi a munkavállalás viszonylagos instabilitását (további részleteket lásd jelen kiadványban R. Fedor Anita (2019) írását). A lakótelepek között egyik kérdésben sem mutatkozott szignifikáns eltérés $(\chi 2(1, \mathrm{~N}=$ $251)=0,300, p=0,662$; Fisher teszt, $p=0,662 ; \chi 2(1, N=198)=1,744, p=0,216$; Fisher teszt, $\mathrm{p}=0,216)$.

\begin{tabular}{|c|c|c|c|c|c|c|}
\hline & $\begin{array}{c}\text { Huszár } \\
\text { lakótelep }\end{array}$ & $\begin{array}{c}\text { Keleti } \\
\text { lakótelep }\end{array}$ & & Összesen & \\
\hline \multirow{2}{*}{ igen } & jelenleg & $\begin{array}{c}\text { elmúlt } 12 \\
\text { hó }\end{array}$ & jelenleg & $\begin{array}{c}\text { elmúlt } 12 \\
\text { hó }\end{array}$ & jelenleg & $\begin{array}{c}\text { elmúlt } 12 \\
\text { hó }\end{array}$ \\
\cline { 2 - 7 } & 100 & 107 & 31 & 37 & 131 & 144 \\
\hline \multirow{2}{*}{ nem } & $53,2 \%$ & $\mathbf{7 5 , 4 \%}$ & $49,2 \%$ & $\mathbf{6 6 , 1 \%}$ & $52,2 \%$ & $\mathbf{7 2 , 7 \%}$ \\
\cline { 2 - 7 } & $46,8 \%$ & $24,6 \%$ & $50,8 \%$ & $33,9 \%$ & $47,8 \%$ & $27,3 \%$ \\
\hline \multirow{2}{*}{} & 188 & 142 & 63 & 56 & 251 & 198 \\
\cline { 2 - 7 } & $100,0 \%$ & $100,0 \%$ & $100,0 \%$ & $100,0 \%$ & $100,0 \%$ & $100,0 \%$ \\
\hline
\end{tabular}

6. táblázat - A jelenlegi- és az elmúlt tizenkét hónapban végzett foglalkoztatás lakótelepek szerinti megoszlása

Forrás: Huszár- és Keleti lakótelepi vizsgálatok, 2019

\section{Kor és iskolai végzettség}

A kor és az iskolai végzettség együttes megoszlását az 7. táblázat mutatja be a mintában és korábbi felmérésekben. A táblázat első és második része már korábban közlésre került (Huszti és mtsai, 2018). Az összehasonlítás okán szerepelnek a korábbi eredmények itt is. A harmadik táblázatrész kiemeli a közép- és felsőfokú képzések arányszámait, amelyek sajnos a várt képet mutatják - szinte kiüresedett ez a táblázatrész. Ennek okairól, hatásairól, következményeiröl a szakirodalomban szá- 
mos elemzés olvasható (a szegénység generációk közötti átörökítése,- 2012; Kapitány, 2012; Hüse és mtsai, 2015; Hüse, 2016; Fábián és mtsai, 2017).

\begin{tabular}{|c|c|c|c|c|c|c|}
\hline $\begin{array}{c}\text { Népszám- } \\
\text { lálás \% } \\
\text { Teljes } \\
\text { Nyíregyháza } \\
\end{array}$ & $\begin{array}{c}1 \\
<8 \text { általá- } \\
\text { nos }\end{array}$ & $\begin{array}{c}2 \\
8 \text { általá- } \\
\text { nos }\end{array}$ & $\begin{array}{c}3 \\
\text { szakiskola } \\
\text { érettségi nélkül }\end{array}$ & $\begin{array}{c}4 \\
\text { érettségi }\end{array}$ & $\begin{array}{c}5 \\
\text { felsőfok }\end{array}$ & Összes \\
\hline $120-29$ & 0,16 & 1,35 & 2,22 & 8,31 & 4,16 & 16,20 \\
\hline $230-39$ & 0,23 & 1,74 & 5,81 & 6,83 & 7,83 & 22,44 \\
\hline $340-49$ & 0,16 & 1,68 & 4,82 & 5,58 & 4,82 & 17,06 \\
\hline $450-59$ & 0,19 & 2,81 & 5,29 & 6,12 & 4,15 & 18,56 \\
\hline $560+$ & 2,41 & 8,81 & 2,73 & 7,32 & 4,47 & 25,73 \\
\hline Összes & 3,15 & 16,39 & 20,87 & 34,16 & 25,43 & 100,00 \\
\hline \multicolumn{7}{|c|}{ Panelkutatás 2018 - Teljes \% } \\
\hline $120-29$ & 0,00 & 0,22 & 2,02 & 16,63 & 4,72 & 23,60 \\
\hline $230-39$ & 0,00 & 0,67 & 2,92 & 5,17 & 6,29 & 15,06 \\
\hline $340-49$ & 0,00 & 0,22 & 1,80 & 7,87 & 5,17 & 15,06 \\
\hline $450-59$ & 0,00 & 0,67 & 2,92 & 5,17 & 6,07 & 14,83 \\
\hline $560+$ & 0,67 & 4,72 & 6,52 & 10,79 & 8,76 & 31,46 \\
\hline Összes & 0,67 & 6,52 & 16,18 & 45,62 & 31,01 & 100,00 \\
\hline \multicolumn{7}{|c|}{ Huszár lakótelep és Keleti lakótelep kutatás 2019 - Teljes \% } \\
\hline $120-29$ & 0,4 & 8,9 & 2,7 & 0,4 & 0,8 & 13,2 \\
\hline $230-39$ & 2,3 & 19,8 & 5,8 & 0 & 0,8 & 28,7 \\
\hline $340-49$ & 3,9 & 13,6 & 5,4 & 0,8 & 0,4 & 24,0 \\
\hline $450-59$ & 5,0 & 10,9 & 3,1 & 0 & 0,0 & 19,0 \\
\hline $560+$ & 4,7 & 6,2 & 3,9 & 0,4 & 0,0 & 15,1 \\
\hline Összes & 16,3 & 59,3 & 20,9 & 1,6 & 1,9 & 100,0 \\
\hline
\end{tabular}

7. táblázat. A kor és az iskolai végzettség a 2011-es népszámlálási adatokban, a 2018-as nyíregyházi Panelkutatás adatfelvételben és a Huszártelep, Keleti lakótelep vizsgálatban Nyíregyháza. Forrás: 2011-es Népszámlálás, Központi Statisztikai Hivatal (www.ksh.hu)

15_3_1_4_3.xls egyedi kérésre összeállított táblázatos adatállomány

\section{Összefoglalás}

Kutatói becslés szerint az adatfelvétel a nyíregyházi Huszártelep lakosságának 25$35 \%$-át fedte le. A Keleti lakótelepen ez az arány ennél is magasabb. A két településrész között nem jelezhető statisztikai különbség a nem, a kor, az iskolai végzettség, a családi állapot és a gazdasági aktivitás mutatóinak tekintetében. 


\section{Irodalom}

1. A szegénység generációk közötti átörökítése. Központi Statisztikai Hivatal, 2012. március 26. Elérhető:

http://www.ksh.hu/docs/hun/xftp/idoszaki/pdf/szegenysegatorokitese.pdf (2019.04.23)

2. Fábián G., Szoboszlai K., Hüse L. (szerk.) (2017): A társadalmi periférián élő gyermekek és fiatalok rizikómagatartásának háttere. Periféria Egyesület, Nyíregyháza.

3. Helyi közösségi fejlesztési stratégia. 2016-2020, átdolgozott változat, Nyíregyháza, 2017. Elérhető:

http://www.clldnyiregyhaza.hu/public/uploadimages/dokumentumok/2018/ HKFS_Nyiregyhaza_2017-10-30_v2.pdf (2019.04.23.)

4. Helynévkönyv (2018) Magyarország közigazgatási helynévkönyve. 2018. január 1. Központi Statisztikai Hivatal, Budapest, 2018. Elérhető: https://www.ksh.hu/docs/hun/hnk/hnk_2018.pdf(2019.04.15.)

5. Huszti É., Hüse L., Takács P., Fábián G. (2018): A „Nyíregyháza Életminősége 2018" vizsgálat és a kutatás módszertana. Acta Medicinae et Sociologica Vol. 9. No. 27: 7-18. doi: 10.19055/ams.2018.9/27/2

6. Hüse L., Szoboszlai K., Gurály E. (2015): Egy falukutatás fókuszában: a gyermekszegénység. Szakkollégiumi Tudástár 3. Evangélikus Roma Szakkollégium, Nyíregyháza.

7. Hüse L. (2016): Az iskolai motivációt befolyásoló tényezők kutatása telepi roma családok körében. In: Kósa Zs. (szerk.): Helyzetkép a magyarországi romákról. Debreceni Egyetemi Kiadó, 45-66.

8. Kapitány B: A hátrányos társadalmi helyzetek generációk közötti átörökítése: egy magyarországi követéses vizsgálat eredményei. Esély, 2012/2.: 3-37. Elérhető: http://www.esely.org/kiadvanyok/2012_2/kapitany.pdf (2019.04.23.)

9. Malakucziné Póka M. (2015): A Nyíregyházi járás települési szerkezeti, demográfiai, háztartási jellemzői. Acta Medicinae et Sociologica Vol. 6. No. 18-19: 11-29. doi: 10.19055/ams.2015.6/18-19/2

10. Monostori P., Öri P., Spéder Zs. (szerk.) (2018): Demográfiai portré 2018. KSH NKI, Budapest: 177-197.

11. Összefoglaló A „Peremhelyzetü és kirekesztett csoportokkal végzett szociális és közösségi munka" c. képzéshez kapcsolódó tanulmányútról. Nyíregyháza, Huszár-telep 2012. szeptember 25. Elérhető:

http://www.melyszegenyseg.hu/dokumentumok/dokumentumtar_tartalma/ tanulmanyut_nyiregyhaza_huszar_telep.pdf (2019.04.23.)

12. R. Fedor Anita, Balla Petra (2019): Foglalkoztatási helyzetkép a telepi körülmények között élő nyíregyházi romák körében. Acta Medicina et Sociologica Vol 10. No.29: 32-44. 